Rural Sociology 78(2), 2013, pp. 229-252

DOI: $10.1111 /$ ruso. 12007

Copyright (C) 2013, by the Rural Sociological Society

\title{
Rural Agricultural Change and Fertility Transition in Nepal*
}

\author{
Prem Bhandari \\ Population Studies Center \\ University of Michigan \\ Dirgha Ghimire \\ Population Studies Center \\ University of Michigan
}

\begin{abstract}
Using longitudinal panel data from the Western Chitwan Valley of Nepal, this study examines the impact of the use of modern farm technologies on fertility transition-specifically, the number of births in a farm household. Previous explanations for the slow pace of fertility transition in rural agricultural settings often argued that the demand for farm labor is the primary driver of high fertility. If this argument holds true, the use of modern farm technologies that are designed to carry out labor-intensive farm activities ought to substitute for farm labor and discourage births in farm families. However, little empirical evidence is available on the potential influence of the use of modern farm technologies on the fertility transition. To fill this gap, the panel data examined in this study provide an unusual opportunity to test this long-standing, but unexplored, argument. The results demonstrate that the use of modern farm technologies, particularly the use of a tractor and other modern farm implements, reduce subsequent births in farm households. This offers important insight for understanding the fertility transition in Nepal, a setting that is experiencing high population growth and rapidly changing farming practices.
\end{abstract}

\section{Introduction}

This study explores perhaps the most empirically examined subject in social demography-rural demographic change, especially the process

\footnotetext{
* This research was supported by a number of grants from the National Institute of Child Health and Human Development (NICHD) (Grant \# R01-HD032912, Grant \# R01HD033551, and Grant \# R01 HD033551-13) and an NICHD center grant to the Population Studies Center at the University of Michigan (R24 HD041028). We thank William G. Axinn (principal investigator) for providing access to the data and feedback on the earlier version of the article. We also would like to thank the staff of the Institute for Social and Environmental Research-Nepal for their contributions to the research reported here and Cathy Sun for assisting with data management. Last but not least, we owe a special debt of gratitude to our respondents who continuously welcome us to their homes and share their invaluable experiences, opinions, and thoughts and have devoted countless hours responding to our survey questionnaires. All errors and omissions remain our responsibility. Address correspondence to Prem Bhandari, Population Studies Center, 426 Thompson Street, Ann Arbor, MI, 48106. E-mail: prembh@isr.umich.edu.
} 
of transition from high fertility to low fertility in a rural agrarian society. Fertility transition has been such an important element of social change that numerous theorists have focused on this rural transition to understand change and variation in fertility processes worldwide. Scholars have identified many societal, household, and individual factors that influence fertility. This body of literature reveals numerous insights regarding the factors affecting dimensions of fertility behavior and has fueled theories designed to explain all or part of the transition from high fertility to low fertility.

While the fertility transition is now universal, scholars also document a large variation in the rate of this transition, with some countries experiencing continued below-replacement-level rates and other countries encountering the early stage of transition. More importantly, this transition varies even among poor nations. For example, some countries in East Asia, North Africa, and Latin America have already completed this transition, whereas other poor, rural, agrarian societies-primarily those in South Asia-are still in the early stage of this transition and continue with relatively high fertility rates (Bongaarts 2008; Gubhaju 2011).

The slow rate of fertility transition, especially in most poor, rural, agrarian societies, has prompted a large stream of research. This research attributes the slow pace of fertility transition to the demand for farm labor as one of the major motivations for childbearing (Cain 1985; Carr, Pan, and Bilsborrow 2006; Filmer and Pritchett 1997; Loughran and Pritchett 1996; Rosenzweig 1977; Rosenzweig and Evenson 1975; Stokes 1995; Togunde and Newman 2005). These studies focus on household land and suggest a positive link between cultivated land size and fertility (Ghimire and Hoelter 2007; Stokes and Schutjer 1984; Tuladhar, Stoeckel, and Fisher 1982). However, in the face of rapidly modernizing farming systems around the world, this literature overlooks the plausible substitution effect of modern farm technologies on farm labor demand and consequently on human fertility (Boserup 1965; Rauniyar and Goode 1996; Self 2008). By examining the relationship between the use of labor-saving farm technology and human fertility in a poor, agrarian setting in Nepal, this study explicitly aims to fill this gap in the literature.

The study of the relationship between farm technology use and fertility transition in rural, agrarian settings holds crucial theoretical and policy implications. From a theoretical perspective, it provides important insights about a fundamental social transformation-fertility transition in rural, agrarian societies. From a policy perspective, a large fraction of the world's population still resides in rural, agrarian settings, and agri- 
culture continues as a fundamental source of livelihood for an estimated 86 percent of the rural population (World Bank 2008). Thus, a better understanding of this relationship will affect a sizable proportion of the world's population. Moreover, a large proportion of people in these rural, agrarian societies continue living in poverty. Population growth in these areas remains high due to relatively high fertility rates. As a result, governments in these countries face the dual challenge of meeting basic needs for the rapidly growing population as well as containing the high population growth rates.

To guide our empirical study of the effects of farm technology use on subsequent household fertility, we construct a theoretical framework that directly builds on the land-labor demand hypothesis and treats the household as a decision-making unit. This framework acknowledges the multidimensional nature of farm technology use and therefore the need to formulate hypotheses in relation to specific dimensions of technologies, rather than assuming technology as a single factor. Additionally, this framework emphasizes the importance of local context for both technology use and human fertility (Axinn and Yabiku 2001; BraunerOtto, Axinn, and Ghimire 2007; Ghimire and Axinn 2010; Yabiku 2004).

To test hypotheses emerging from this framework, we use detailed data from the Western Chitwan Valley-a rural, agrarian setting in Nepal. This valley is an ideal setting for this study. Until recently, subsistence-based agriculture predominated in the valley with virtually no use of modern farm technology. In addition, fertility limitation was not an option for individuals because of cultural reasons as well as the limited availability of modern contraceptive methods (Bennett 1983; Fricke 1988; Tuladhar 1989). However, recent changes in social, economic, and institutional contexts in the valley stimulated a dramatic transition away from subsistence farming to a more commercialized farming system (increasing dependency on chemical fertilizers, pesticides, and mechanical technologies). Similarly, these same changes also stimulated a rapid increase in age at first marriage and contraception, and subsequently a decline in marital fertility, thus influencing rapid demographic transition (Axinn and Yabiku 2001).

The data used in this study document change and variation in both household farm technology use and the number of births in those households. These data also include uniquely detailed measures of household socioeconomic characteristics, agricultural practices, and household members' nonfamily, marital, and childbearing experiences. Of particular interest, these data provide measures of multiple dimensions of farm technology use beginning in 1996, along with a monthly record of births in each household in subsequent years, thus offering an 
unusual opportunity to study the relationship between modern technology use and household fertility — number of babies born to a farm household. Because increasing food production and reducing population pressure on the land are both high priorities for rural, agrarian societies (Ashby and Pachico 1987; Stokes and Schutjer 1984), this study makes a valuable contribution to understanding an important dimension of rural demographic change-fertility transition in a rapidly changing, rural, agrarian setting.

\section{Theoretical Framework}

Fertility transition remains such a consequential component of population dynamics that numerous studies focus on this phenomenon to understand change and variation in fertility processes worldwide. A large body of demographic research identifies several individual-level factors that influence fertility-education, employment, exposure to media, religion, orientation about family and family formation, and attitudes about family and family formation (Blossfeld and Huinink 1991; Brien and Lillard 1994; Caldwell 1982; Hirschman 1985; Hirschman and Rindfuss 1980; Notestein 1953). This research also recognizes the influence of family and household factors such as parents' education, work, and exposure to media on fertility behavior (Axinn and Yabiku 2001; Caldwell, Reddy, and Caldwell 1983). Finally, these factors also include various dimensions of social context, such as the spread of nonfamily services (Axinn and Yabiku 2001), mass education (Axinn and Barber 2001), family planning policy (Entwisle and Mason 1986), and family planning programs (Brauner-Otto et al. 2007; Entwisle, Casterline, and Sayed 1989). However, despite this wealth of existing knowledge, scholars also note a large variation in fertility levels, particularly between predominantly rich, industrialized countries and poor, rural, agrarian countries. This variation in fertility levels has prompted a stream of research that focuses on changes in farming practices in rural, agrarian societies.

\section{Agricultural Modernization and Human Fertility}

Similar to fertility transition, a dramatic shift occurred in world agriculture during the second half of the 20th century, away from traditional farming systems toward increasingly mechanized, commercial farming systems with many socioeconomic, environmental, and political implications (Majumdar, Dolui, and Banerjee 2001; Mamdani 1972; Self 2008; Vosti, Witcover, and Lipton 1994). Proponents of the technological revolution in agriculture-including agricultural modernization-have 
greatly emphasized the positive aspects of transitioning away from traditional, subsistence farming to mechanized, commercial farming. These positive aspects include increases in food production and productivity, declines in food prices, and overall socioeconomic development (for example, Hazell and Ramaswamy 1991; Lipton 1989; Mellor 1976; Sen 1975; Vosti et al. 1994).

However, this transition from subsistence, family-based farming to highly mechanized, oil-based, commercial farming is not without cost. Scholars are genuinely concerned about the unintended negative consequences of this green revolution. Such negative consequences include price inflation of agricultural commodities, detrimental health effects, and negative environmental outcomes such as air and water pollution potentially leading to global warming and climate change (Biswas 1994; Cleaver 1972; Griffin 1974; Hill et al. 2009; Jacoby 1972; Pimentel and Pimentel 1991; Shiva 1993). Additionally, because these modern technologies are designed to perform labor-intensive jobs and are labor saving in nature (Boserup 1965; Rauniyar and Goode 1996), the use of modern farm technologies replaces farm labor, thus producing surplus labor and unequal distribution of economic benefits, which may lead to possible peasant revolutions (Cleaver 1972; Griffin 1974; Jacoby 1972; Paige 1975; Scott 1977; Skocpol 1982; Wolf 1969). Consequently, because demand for farm labor is identified as a major driver of human fertility in poor, agrarian societies, the reduction in the demand for farm labor may also shape individuals' fertility preferences, perhaps differently by sex.

Considering the consequences of agricultural modernization on human population and environmental conditions, scholars and policymakers remain interested in understanding the link between agricultural mechanization and population dynamics, including individual fertility behavior. Scholars use multiple frameworks to explain fertility behavior in agrarian societies (Rosenzweig 1977; Stokes and Schutjer 1984). These frameworks emphasize the demand for farm labor, particularly the labor contributed by children, as an important driver of human fertility. Since children in agrarian societies frequently perform various farm activities (Cain 1977) and are considered durable commodities that yield both psychic income and productive labor (Rosenzweig 1977), these scholars highlight the value of child labor as an important driver of fertility preferences and behavior.

This line of inquiry posits two hypotheses: the land-security hypothesis and the land-labor demand hypothesis (Stokes and Schutjer 1984). The land-security hypothesis presents land as a substitute for children for parental old-age security, suggesting a negative relationship between 
landownership and marital fertility (Cain 1981, 1985; Jensen 1990). Thus, landownership should reduce the value of children as a source of parental security in old age and, therefore, lower motivation for additional children. On the other hand, the land-labor demand hypothesis suggests a positive relationship between operational landholding and fertility (Cain 1981, 1985). The size of operational landholding affects fertility by altering the cost-benefit ratio of additional children. The households with access to larger operational landholdings use additional family labor more profitably than those with smaller operational landholdings and, therefore, prefer more children. These two perspectives are important in thinking about fertility in agrarian societies. However, in the face of rapidly changing world agriculture, these frameworks overlook the plausible substitution effect of modern farm technologies on farm labor demand and consequently on human fertility (Boserup 1965; Rauniyar and Goode 1996; Self 2008). Thus, building on this literature, we construct a new theoretical framework to guide our examination of the consequences of the use of modern farm technologies for subsequent fertility behavior. Although the technological revolutionincluding agricultural modernization-influences both human population and the global environment with significant socioeconomic, demographic, political, and environmental consequences, because of the modest scope of this article we focus on one specific demographic consequence-household fertility.

\section{The Link between Modern Farm Technology Use and Human Fertility}

Traditionally, farming in rural, agrarian societies is commonly performed by using human and animal labor. However, this practice is changing dramatically worldwide. It is well documented that tractors are gradually replacing the animal and human labor generally used in land preparation (Agarwal 1983; Bartsch 1977; Biggs, Justice, and Lewis 2011; Binswanger 1978; Schutjer and Van der Veen 1977). For example, according to Agarwal (1983), using a tractor requires only one fifth of the labor needed when using a bullock. In addition, farmers are increasingly using farm implements such as corn shellers, threshers, sprayers, and chaff cutters (Mamdani 1972; Pariyar, Shrestha, and Dhakal 2001). Altogether, these farm implements replace the need for human labor. Evidence from India suggests that mechanical threshing of wheat reduced about 71 man-hours per hectare of land (Binswanger 1978). Therefore, there is reason to believe that the decline in the demand for labor due to use of mechanical technology (here, tractor and farm implements) reduces the value of children, thus leading to declining 
motivation for childbearing. Considering this evidence of the laborreplacement effects of mechanical farm technologies, combined with the established link between the need for farm labor and high fertility as envisioned by the land-labor demand hypothesis, we posit that:

H1. The use of a tractor reduces the demand for farm labor by replacing human labor, thus reducing births in farm households.

H2. The use of farm implements also reduces the demand for farm labor by replacing human labor, thus reducing births in farm households.

Moreover, farmers in rural, agrarian societies commonly use farmyard manure or compost for replenishing soil nutrients. However, more recently, farmers have been increasingly using chemical fertilizers instead of manure or in a combination of both. Manure is generally applied by hand. Although fertilizer drills, seed drills, and row planters can also be used to apply chemical fertilizers, the most common practice is either by hand or by using a scoop and basket (Bartsch 1977). Unfortunately, comparative studies on the labor requirements of various methods of manure application are scarce and the available evidence is inconclusive. Anecdotal evidence, however, suggests that the application of farmyard manure demands a much higher level of human labor than the use of chemical fertilizers. This is because a household is required to keep livestock to produce the manure, which necessitates a regular supply of labor for livestock care and management. Moreover, the barn must be cleaned and compost must be prepared and then carried out to the field for application. These tasks require a significant amount of labor in contrast to buying, storing, and applying chemical fertilizer. Therefore, we hypothesize that:

H3. The use of a chemical fertilizer reduces the demand for farm labor by replacing human labor, thus reducing births in farm households.

The application of pesticides (herbicides and insecticides) can also replace manual labor. Herbicides are used for controlling weed growth in crop fields and insecticides for controlling insects and diseases. Rani and Malaviya (1992) reported that one acre of land requires 12.42 days of manual weeding. However, with herbicide application, the time required for weed control decreased to 0.42 days per acre. Therefore, we hypothesize that:

H4. The use of pesticides reduces the demand for farm labor by replacing human labor, thus reducing births in farm households. 


\section{Setting, Data, and Methods}

\section{Setting}

The setting for this study is the Western Chitwan Valley, situated in the southern plain of central Nepal. Before the 1950s, the valley was primarily covered with dense forests and was infamous for malarial infestation. With U.S. assistance, however, the Nepalese government initiated a rehabilitation program in the valley during the 1950 s by clearing these dense forests. Since then, the area has witnessed a rapid inflow of migrants attracted by the free distribution of land for agricultural purposes at the beginning of the settlement, and by the subsequent growth of modern amenities and services in recent decades. Currently, the valley is inhabited mostly by in-migrants, especially from the hill and the high hill and other adjacent Terai districts, including India. Moreover, Chitwan's central location and relatively well-developed transportation network have been the catalytic forces for transforming it into a hub for business and tourism. This has resulted in a rapid proliferation of government services, businesses, and wage labor opportunities in the district (Shivakoti et al. 1999).

Farming remains the key source of livelihood in the valley. Although agriculture is experiencing modernization, it remains mostly subsistence in nature. A large majority of farmers practice mixed farming with highly integrated crop-livestock production systems. Households cultivate land to produce food grains and raise livestock for animal protein (milk, meat, and eggs), draft power, and manure. Family labor, including child labor, is commonly used to perform various farm and nonfarm activities. To a large extent, the labor needed for performing these activities originates within the household. More recently, however, the family mode of agricultural production has been rapidly changing throughout Nepal (Ministry of Agriculture and Cooperatives 2003; Pariyar et al. 2001). Traditional, labor-intensive farming practices, such as land preparation, application of farmyard manure, and threshing of grains, are gradually being replaced by modern farm technologies such as a tractor, updated farm implements, and biochemical advancements.

\section{Data}

This study used multiple data sets collected by the Chitwan Valley Family Study (CVFS) since 1996: neighborhood histories, household census, household agriculture and consumption surveys, individual interviews with life history calendars, and a prospective monthly household demographic event registry. 
Data to test our hypotheses came from a study of 151 neighborhoods scattered throughout the Western Chitwan Valley. For the purposes of this study, we defined a neighborhood as a geographic cluster of five to fifteen households. We chose these neighborhoods as an equal probability, systematic sample of neighborhoods in Western Chitwan, and the characteristics of this sample closely resemble the characteristics of the entire Chitwan Valley population (Barber et al. 1997). Once a neighborhood was selected, we collected a history of each neighborhood using a calendar method (Axinn, Barber, and Ghimire 1997). The neighborhood history data collection was followed by household census and household agriculture and consumption surveys. Once the household survey was completed, we also interviewed all individuals aged 15 to 59 residing in the sampled households using a standardized questionnaire and life history calendar (Axinn, Pearce, and Ghimire 1999).

Finally, in 1997, the CVFS started the prospective monthly household demographic registry that monitors demographic events such as living arrangement, marriage, birth, migration, and deaths for each month since 1997. For this study, we utilized the number of babies born to a household as the outcome variable, which was updated from the household registry over a period of 115 months since 1997 .

We used a sample of 970 farm households in 1996 that had at least one married woman between the ages of 15 and 45 . Because we measured the outcome, number of births in a household, prospectively, we used the measures of household farm technology use and other household characteristics as predictors.

The 1996 household census collected information on age, sex, marital status, and relationship with the members of the household for each person in a household. This survey included all the individuals who ate and slept most of the time in a given household during the previous six months. The household agriculture and consumption survey collected information on household resources and assets, consumption, and agricultural practices. Of particular interest, the survey collected specific information on the use of various technologies such as tractors, chemical fertilizers, pesticides, and farm implements in crop production, along with other information such as the size of cultivated land, landownership, and livestock holdings. Researchers collected the data using faceto-face interviews featuring a carefully designed, interviewer-assisted, structured schedule with more than a 99 percent response rate. The information about other controls-such as the number of nonfamily community services and the distance to the largest market center of Narayangarh-came from the neighborhood data. 


\section{Measures}

Measure of household births. The number of babies born to women living in households over 115 months since 1997, referred to as household fertility in this study, is the dependent variable. We define a farm household as a dwelling unit that reported farming and has at least one married woman aged 15-45 years at the time of the 1996 survey. Beginning in 1997, the prospective monthly household demographic registry provided monthly updates on the childbearing status of each woman of childbearing age living in the household. We counted the total number of live births in each household since 1997 for the subsequent 115 months to obtain the number of babies born in a household.

Measures of farm technology use. Researchers measured use of modern farm technologies such as a tractor, farm implements, chemical fertilizers, and pesticides in crop production by a farm household in 1996 prior to the measurement of household births. This provides an unusual opportunity to examine the possible causal relationships between the use of modern farm technology and subsequent childbirths.

Tractor use. We measured use of a tractor with the survey item asking, "Did your household use a tractor to plough the land for plantingcrop?"; we coded the variable " 1 " if that household used a tractor and " 0 " if not.

Farm implements use. We considered ownership of modern farm implements - a thresher, chaff cutter, sprayer, corn sheller, or other implement - an indicator of the use of improved implements by a farm household. We coded the variable " 1 " if a household owned any of these implements and "0" otherwise.

Chemical fertilizer and pesticide use. We measured use of chemical fertilizers by asking, "Did you use chemical fertilizer in the past three years?" We asked a similar question for pesticide use. We recorded the answer " 1 " if a household used these chemicals and " 0 " if not. We used these two dichotomous measures separately in the analysis.

\section{Controls}

As mentioned above, since individual fertility and technology use are influenced by a large array of individual, parental, household, and community factors, we also included a series of controls known to shape the relationship between fertility and technology use. These controls include number of married women of childbearing age, number of female and male children per married woman, children's schooling status, education of the head (senior person), contraceptive use, women's occupation, land size, landownership, number of animals in 
the household, ethnicity, access to nonfamily services, and distance to Narayangarh. These controls are fairly standard in literature on technology use and fertility. We measured them as follows.

Number of married women aged 15-45. We measured this control as the number of women aged 15-45 years living in a farm household at the time of the 1996 survey.

Number of female and male children per married woman. Because present parity influences future births and because there is evidence of son preference in Nepal (Leone and Zuanna 2003; Stash 2001), we controlled for the average number of female and male children born to a married woman in or before 1996. We calculated both of these measures by dividing the total number of female and male children in the household born before 1996 by the total number of married women aged 15-45 in the household.

Children (aged 6-15) currently in school. We also adjusted for children's schooling, which is found to be a key determinant of their parents' fertility (Axinn and Barber 2001; Caldwell 1980; Rosenzweig and Evenson 1975). We coded children aged 6-15 currently in school as "1" and " 0 " otherwise.

Education. Education is an important determinant of fertility. We used the education level of the oldest male member, who may be considered the head of a household, measured as the number of years of schooling. If there was no male in the household, we used the education level of the oldest female.

Contraceptive use. We also controlled for any modern contraceptive ever used by an individual in the household (coded " 1 ") or not (coded "0").

Women in a salaried job. Women's employment increases their autonomy as well as the opportunity cost of childbearing, both negatively influencing fertility (Mason 1987; Waite and Stolzenberg 1976). We coded women as " 1 " if they were in a salaried job and " 0 " if they were not.

Size of cultivated land and landownership. According to the land-labor demand hypothesis, households with a large area of operational holding demand more labor, thus motivating farmers to produce more children (Stokes and Schutjer 1984). For this purpose, we control for total size of cultivated land by a farm household. Similarly, according to the old-age security hypothesis, children are considered a form of risk insurance or a source of support during old age (Caldwell 1982; Mason 1987). Landownership can serve as collateral against loans or as a means of financial support during old age (Stokes and Schutjer 1984). For this reason, we controlled for landownership, coding full owner-cultivators as " 1 " and part owners and sharecroppers as " $0 . "$ 
Number of animals in the farm household. Keeping livestock is an integral part of the farming system in the valley. Because caring for these animals demands a substantial amount of adult and child labor, the demand for children may be associated with the size of the livestock holding (de Sherbinin et al. 2008). For this reason, we controlled for the total number of large animals-cattle and buffaloes-owned by a farm household.

Ethnicity. Previous studies reported variation in fertility preferences by ethnicity in this setting (Axinn and Barber 2001; Biddlecom, Axinn, and Barber 2005), and our analysis therefore controlled for ethnicity. Following the common practice in this setting (Axinn and Barber 2001), we grouped households into Bhramin-Chhetri (high-caste Hindu), Dalit (low-caste Hindu), hill Janajati (indigenous), Newar, and Terai Janajati (indigenous) with the Bhramin-Chhetri group as the reference category.

Access to nonfamily services. Access to nonfamily services such as schools, health services, banks, cooperatives, transportation, and employment centers also influences fertility (Axinn and Barber 2001; Axinn and Yabiku 2001; Brauner-Otto et al. 2007; Ghimire and Axinn 2010). In the CVFS survey, all of these measures were recorded as the walking distance (in minutes) to the nearest service from the neighborhood. Since most of these services are likely to be concentrated in one place and are highly correlated with walking time, we constructed an index to measure the degree of accessibility to these services. The index ranges from 0 to 6 - " 0 " refers to no services within a 10-minute walk, and " 6 " refers to the presence of all six services within a 10-minute walk.

Distance to Narayangarh. Narayangarh is the largest urban center, and the administrative headquarters, of the Chitwan District. This city is an important source of information and of off-farm employment opportunities. We used distance to Narayangarh (measured in kilometers) as a control in our analysis.

\section{Analytical Strategy}

We used a multistep analytical strategy to estimate the relationship between farm technology use and household fertility. First, we calculated the univariate distribution of all measures used in the analysis. Second, we examined the differences in childbirths by farm technology use using a one-way ANOVA (results not shown). Finally, we estimated multivariate models to examine the relationships between farm technology use and household fertility, adjusting for the effects of other controls known to influence fertility using the ordinary least squares (OLS) technique. We 
first estimated the effects of each farm technology separately, and finally combined them together in a single model.

\section{Results}

We present results in the order outlined in the theoretical framework. However, before the article moves into the details of the multivariate analyses, a brief discussion of some descriptive statistics follows.

\section{Descriptive Statistics}

Table 1 presents the mean, median, standard deviation, and minimum and maximum values for the measures of household fertility, farm technology use, and controls. The mean of 1.49 (range of 0 to 10) for number of babies born indicates that, on average, a sample farm household had one and a half births during the 115-month period. The bivariate comparison (ANOVA, results not shown) suggests that, in general, fewer births were reported in households that used modern farm technologies. However, the mean difference was statistically significant only for those who used a tractor versus those who did not use a tractor.

Notably, we observed variations in modern farm technology use. In 1996, for example, 77 percent of farm households reported the use of a tractor for land preparation, whereas 15 percent of farm households reported owning any modern farm equipment (such as corn shellers, threshers, sprayers, and chaff cutters). Similarly, 83 percent of farm households reported the use of chemical fertilizers while approximately 24 percent reported the use of pesticides.

A farm household had slightly more than one married woman aged 15-45 years in 1996. The mean numbers of girls and boys already born to a married woman on or before 1996 were both close to 1.5.

About three fourths of farm households reported that at least one child (aged 6-15) was currently enrolled in school. The average years of schooling of the household head was close to four and a half years. In more than half of the households, any individual had ever used a modern contraceptive. Very few farm households reported at least one woman in a salaried job.

The average size of cultivated land per farm household was less than a hectare. However, half of the farm households had nearly two thirds of a hectare of land ( 1 bigh $a=20$ kattha $=0.67$ hectare $)$. More than two thirds of farm households owned either bari or khet land or both. On average, a household owned nearly three large animals (cattle and buf- 
Table 1. Descriptive Statistics of Measures ( $N=970$ Households).

\begin{tabular}{|c|c|c|c|c|c|}
\hline \multirow[b]{2}{*}{ Measures } & \multicolumn{5}{|c|}{ Descriptive Statistics } \\
\hline & Mean & Median & $\begin{array}{l}\text { Standard } \\
\text { Deviation }\end{array}$ & Minimum & Maximum \\
\hline \multicolumn{6}{|l|}{ Household birth } \\
\hline $\begin{array}{l}\text { Number of babies born (in } 115 \\
\text { months since 1997) }\end{array}$ & 1.49 & 1.00 & 1.66 & 0.00 & 10 \\
\hline \multicolumn{6}{|l|}{$\begin{array}{l}\text { Farm technology use (measured } \\
\text { in 1996) }\end{array}$} \\
\hline Tractor use $($ yes $=1)$ & 0.77 & - & 0.42 & 0 & 1 \\
\hline Farm implements use $($ yes $=1)$ & 0.15 & - & 0.36 & 0 & 1 \\
\hline $\begin{array}{l}\text { Chemical fertilizer use } \\
\quad(\text { yes }=1)\end{array}$ & 0.83 & - & 0.37 & 0 & 1 \\
\hline Pesticide use (yes $=1$ ) & 0.24 & - & 0.43 & 0 & 1 \\
\hline \multicolumn{6}{|l|}{ Controls (measured in 1996) } \\
\hline $\begin{array}{l}\text { Number of married women } \\
\quad \text { (age } 15-45 \text { per household) }\end{array}$ & 1.13 & 1.00 & 0.42 & 1 & 4 \\
\hline $\begin{array}{l}\text { Number of female children per } \\
\text { married woman }\end{array}$ & 1.46 & 1.00 & 1.27 & 0 & 7 \\
\hline $\begin{array}{l}\text { Number of male children per } \\
\text { married woman }\end{array}$ & 1.44 & 1.00 & 1.01 & 0 & 6 \\
\hline $\begin{array}{l}\text { Children (age 6-15) currently } \\
\quad \text { in school }(\text { yes }=1 \text { ) }\end{array}$ & 0.76 & - & 0.42 & 0 & 1 \\
\hline $\begin{array}{l}\text { Education of the household } \\
\text { head (years) }\end{array}$ & 4.45 & 4.00 & 4.55 & 0 & 16 \\
\hline $\begin{array}{l}\text { Any individual in the } \\
\text { household used a modern } \\
\text { contraceptive }(\text { yes }=1)\end{array}$ & 0.56 & - & 0.59 & 0 & 1 \\
\hline $\begin{array}{l}\text { Women in salaried job } \\
\quad(\text { yes }=1)\end{array}$ & 0.07 & - & 0.28 & 0 & 1 \\
\hline Size of cultivated land (kattha) & 25.89 & 19.00 & 24.25 & 1 & 200 \\
\hline $\begin{array}{l}\text { Landownership (full owner }= \\
\text { 1) }\end{array}$ & 0.70 & - & 0.46 & 0 & 1 \\
\hline $\begin{array}{l}\text { Number of animals in the } \\
\text { household }\end{array}$ & 2.73 & 2.00 & 2.73 & 0 & 14 \\
\hline \multicolumn{6}{|l|}{ Ethnicity } \\
\hline $\begin{array}{l}\text { Bhramin-Chhetri (high-caste } \\
\text { Hindu) }\end{array}$ & 0.49 & - & 0.50 & 0 & 1 \\
\hline Dalit (low-caste Hindu) & 0.11 & - & 0.31 & 0 & 1 \\
\hline $\begin{array}{l}\text { Hill Janajati (hill } \\
\text { indigenous) }\end{array}$ & 0.15 & - & 0.36 & 0 & 1 \\
\hline Newar & 0.05 & - & 0.23 & 0 & 1 \\
\hline $\begin{array}{l}\text { Terai Janajati (Terai } \\
\text { indigenous) }\end{array}$ & 0.19 & - & 0.40 & 0 & 1 \\
\hline $\begin{array}{l}\text { Access to nonfamily services } \\
\text { (number of services) }\end{array}$ & 2.21 & 2.00 & 1.47 & 0 & 6 \\
\hline Distance to Narayangarh $(\mathrm{km})$ & 9.09 & 9.68 & 3.74 & 0.04 & 17.7 \\
\hline
\end{tabular}

Note $: 30$ kattha $=1$ hectare $=2.471$ acres 
faloes). By ethnicity, about half of farm households were BrahminChhetri, while less than 20 percent each were Dalit, hill Janajati, Newar, and Terai Janajati.

Regarding access to nonfamily services, of the six nonfamily services included, slightly over two services were available within a 10-minute walk. The average distance from the sample neighborhoods to the main urban center (Narayangarh) was almost 10 kilometers, with a minimum of less than a kilometer and a maximum of about 18 kilometers.

\section{Multivariate Analysis}

Models 1 through 6 in Table 2 display the OLS estimates of the multivariate models of farm technology use and household fertility. Guided by our modeling strategy, we began with a simple model of controls only (Model 1). This basic model is followed by Models 2 to 5, which separately examined the effects of each farm technology use measure (tractor, farm implements, chemical fertilizers, and pesticides, respectively) on household births, adjusting for the controls in Model 1. We also estimated a combined model (Model 6) that simultaneously examined the independent effects of the four measures of farm technology use on household births net of controls.

In Model 1 of Table 2, the effects of most of the controls are in the expected direction. For example, the number of reproductive aged women, size of cultivable land, and number of livestock each has a strong positive, statistically significant effect on number of household births. On the other hand, number of male children, education, and having a person in the household who ever used any modern contraceptive each has a strong negative, statistically significant effect on number of household births. These results are consistent with the previous findings from Nepal and in the region (Acharya 1998; Axinn and Barber 2001; Rosenzweig and Evenson 1975; Suwal 2001). Similarly, the effect of size of operational land holding on household fertility is positive and statistically significant. This result is also consistent with the land-labor demand hypothesis and previous findings (Frost 2010; Ghimire and Hoelter 2007; Tuladhar et al. 1982). Although the effect of landownership is not statistically significant, the relationship is in the expected direction. The effect of the number of large animals on household fertility is also as expected.

Impact of tractor use. Model 2 of Table 2 displays the effect of tractor use on number of births in a farm household. As expected, tractor use has a strong, negative, statistically significant effect on the number of babies born to the household. The OLS regression coefficient of -0.240 


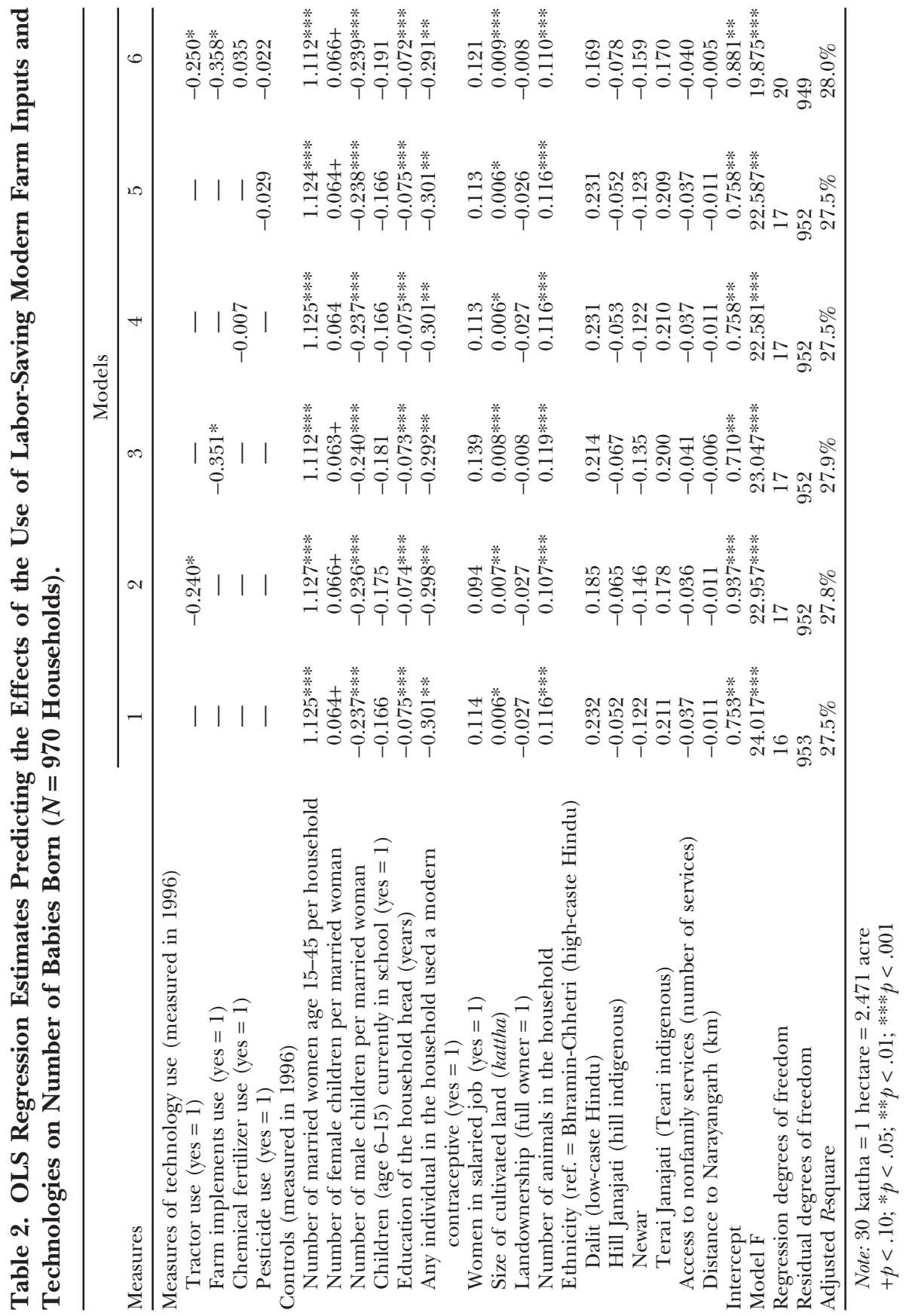


suggests that compared to the households that did not use a tractor, the households that used a tractor are likely to have 0.24 fewer babies. This effect is consistent with our first hypothesis-the labor-substitution hypothesis, which suggests that the use of a tractor reduces the demand for farm labor by replacing human labor, thus reducing births in farm households.

Impact of farm implements use. Model 3 of Table 2 displays the effect of modern farm implement use on number of babies born to the farm household. Results show that the use of farm implements also has a strong, negative, statistically significant effect on the number of babies born to the household, as expected. The OLS regression coefficient of -0.351 suggests that compared to the households that did not use any farm implement, the households that used farm implement are likely to have 0.351 fewer babies. Again, the negative effect of farm implement use is consistent with our second hypothesis, suggesting that the use of labor-saving farm implements reduces the number of births in a farm household.

Impact of chemical fertilizer and pesticide use. In Models 4 and 5 of Table 2, we estimated the effects of the uses of biochemical farm technologies (chemical fertilizers and pesticides, respectively) on household fertility. Although the effects of the uses of chemical fertilizers and pesticides are in the expected direction, the effects are not statistically significant. These results are consistent with those of Self (2008), who reported evidence that compared to biological farm technologies, mechanical farm technologies are the primary driving force behind fertility reduction.

Independent effects of technology use. Finally, in Model 6 of Table 2 (the combined model), all four measures of farm technology use are included in a single model net of controls examined in Model 1. The results show that there is little change in the effects of the measures of technology use on number of births in a farm household. The effects of both use of a tractor and farm implements in Model 5 remained similar to that of the single models (Model 1 and Model 2). This suggests that the use of a tractor and farm implements influence the number of children born to a farm household independently. This study thus finds substantial and statistically significant independent effects of key dimensions of mechanical farm technology use.

\section{Discussion and Conclusion}

As hypothesized, this study finds important effects of the use of laborsaving farm technologies on household fertility. The results provide 
strong evidence of a negative association between the use of labor-saving farm technologies-particularly the use of a tractor and farm implements-and household fertility. More importantly, the effects we documented here are net of various community, household, and individual factors known to influence fertility preferences and behavior. These findings suggest that the demand for farm labor could be the driving force behind persistently high fertility in poor, rural, agrarian settings, and, therefore, the use of mechanical farm technologies may speed up a fertility transition in such settings.

Interestingly, however, we did not find any significant effect of the use of chemical fertilizers and pesticides on human fertility. There are several potential explanations for the statistically nonsignificant effects of biochemical farm technologies. One possible reason is that farmers in the valley still continue to use farmyard manure along with chemical fertilizers. In a fertilizer use study conducted in 2003 by the Ministry of Agriculture and Cooperatives, about 81 percent of households used both chemical fertilizers and farmyard manure in Nepal. Another possible explanation is that the tasks of weeding and removing diseased or insectinfested plants are still performed by human labor and have not been completely replaced by the use of biochemical farm technologies. In addition, pesticides are generally applied to commercially grown crops, such as fruits and vegetables, to ensure high-quality products (Biswas 1994). Most farmers in the valley still cultivate traditional crops such as paddy rice, maize, wheat, and mustard, and the commercial production of fruits and vegetables is limited. Although recent evidence is not available, in 1991-92, less than 15 percent of farm households used pesticides on paddy rice, maize, wheat, and vegetables (Bastola 1998). Because of their minimal use, the labor-replacement effects of chemical fertilizers and pesticides may not be as significant as that of mechanical farm technologies, and thus they may have less influence on the number of births in a household.

The data presented here provide insight into the pace of fertility transition in poor, rural, agrarian societies, and hold both theoretical and practical significance for populations in Nepal and similar settings. From a theoretical perspective, this study tests the theoretical relationships between the uses of labor-saving farm technologies and household fertility by examining the household, longitudinal panel data. The findings also have important practical significance for the rural agrarian setting of Nepal and other countries of South Asia (for example, Bangladesh, India, and Pakistan). In these settings, human populations are growing rapidly and food production is barely meeting the needs of these expanding populations. Specifically, South Asian countries, with 
one quarter of the world's population, continue to have relatively high fertility rates and low contraceptive prevalence (with the exception of Sri Lanka and parts of southern India) despite the relatively early onset of the fertility transition in many neighboring countries of Southeast Asia (ESCAP 2007; Sathar and Phillips 2001). Additionally, the persistently high fertility rates in the region are somewhat surprising given the long-standing, antinatalist population policies and programs. For these reasons, this region has been the center of attention for fertility studies (Caldwell and Caldwell 2003; Sathar and Phillips 2001). Because two important policy goals in these rural agrarian settings are to increase agricultural output while slowing down population growth (Schutjer and Stokes 1982), the findings are particularly valuable and relevant.

While this study addresses an important gap in previous research, it has its own limitations, which provide directions for future work. From a methodological perspective, first, this study was unable to control for whether a household shares or hires labor for agricultural operations. The survey lacks this particular measure. Second, the findings are based on data from only one part of the southern Nepal Terai plain, and, therefore, may not be generalizable to the hill and high hill districts. Third, a related limitation is that the findings regarding mechanical farm technology use may not be appropriate for policy purposes for the hill and mountain districts of Nepal, where machines, such as tractors, cannot be used because of topographical difficulties. This suggests the need for further studies in other parts of the country while taking into account the particular geographical terrain and needs of each district.

Moreover, from a societal perspective, there are controversies about the economic benefits, employment and health effects, and environmental impact of modern farm inputs and technology use worldwide. The consequences of the green revolution technologies including farm mechanization are likely to go beyond fertility transition. For example, the results of the shift from traditional farming to commercial farming in peasant economies may include unequal distribution of economic benefits (Cleaver 1972; Griffin 1974; Jacoby 1972), unemployment effects (Cleaver 1972; Griffin 1974; Jacoby 1972), and possible peasant revolutions (Paige 1975; Scott 1977; Skocpol 1982; Wolf 1969). Scholars have also argued that agricultural modernization or the use of modern farm technologies largely benefit larger farmers (Cleaver 1972; Griffin 1974; Jacoby 1972). Jacoby (1972) believed that the green revolution has not resulted in socioeconomic development-particularly in South Asia-but rather has shaken the economic foundation of the agricultural population in these countries. Some argue that the rural poor do not receive a fair share of the benefits generated from the green revolution. 
Additionally, from an environmental perspective, the uses of chemical fertilizers and pesticides may jeopardize the environment by leaching out chemicals into bodies of water, poisoning food, and damaging insects and other pests (Biswas 1994; Pimentel and Pimentel 1991). Similarly, the use of oil-based farm technologies (such as tractors) may have serious environmental consequences affecting global climate change (Hill et al. 2009). Although switching to oil-based agricultural practices may help reduce population, the production of carbon dioxide and other oil-based emissions are problematic and negatively affect global climate change.

Although the technological revolution-including agricultural modernization-significantly influences both human populations and the global environment in multiple ways with several important consequences, because of the modest scope of this article, we focused on only one specific consequence, household fertility, and therefore do not answer other concerns. For example, it is not clear how farm families perceive this issue of reduced farm births due to the use of labor-saving farm technologies. Do couples in farm households consciously reduce number of babies now because they do not need more children as farmhands? There are reasons to believe that couples in farm households make such decisions consciously. Evidence from this setting suggests that most couples discuss the number of children they want to have and whether to use family planning methods to delay or stop childbearing. In addition, the findings also show that those who discuss these issues are significantly more likely to use contraceptives (Link 2011). However, further study is needed to understand whether couples discuss the reasons for reducing the number of births or for using contraceptives; that is, whether it is specifically due to less demand for farmhands or to other reasons. Other questions that remain unanswered are how couples (men or women) make the final decision to stop childbearingis it the husband or the wife? Who decides how many children to have or does the couple jointly decide it? And how do couples reduce the number-contraception? Abstinence? Delay of marriage? Or a combination of all different means? Moreover, the consequences of the uses of these labor-saving farm technologies for various aspects of the economy, society (including gender relations), and the environment must be considered before formulating policy, which is a big challenge ahead. Specifically, it is crucial to gain a better understanding of the environmental and health effects caused by the use of chemical fertilizers and pesticides, along with the potential unemployment effects on both men and women due to the labor-replacement effects of modern labor-saving farm technologies, particularly the use of oil-based farm technologies. 


\section{References}

Acharya, Laxmi Bilas. 1998. "Determinants of Fertility in the 1970s and 1990s in Nepal." Contribution to Nepalese Studies 25 (spec. issue):95-108.

Agarwal, Bina. 1983. Mechanization in Indian Agriculture: An Analytical Study Based on the Punjab. Delhi School of Economics Monograph in Economics No. 6. New Delhi, India: Allied.

Ashby, Jacqueline A. and Douglas Pachico. 1987. "Agricultural Ecology of the Mid-hills of Nepal." Pp. 195-222 in Comparative Farming Systems, edited by B. L. Turner II and S. B. Brush. New York: Guilford Press.

Axinn, William G. and Jennifer S. Barber. 2001. "Mass Education and Fertility Transition." American Sociological Review 66:481-505.

Axinn, William G., Jennifer S. Barber, and Dirgha J. Ghimire. 1997. "The Neighborhood History Calendar: A Data Collection Method Designed for Dynamic Multilevel Modeling." Sociological Methodology 27:355-92.

Axinn, William G., Lisa D. Pearce, and Dirgha J. Ghimire. 1999. "Innovations in Life History Calendar Applications." Social Science Research 28(3):243-64.

Axinn, William G. and Scott Yabiku. 2001. "Social Change, the Social Organization of Families, and Fertility Limitation." American Journal of Sociology 106(5):1219-61.

Barber, Jennifer S., Ganesh Shivakoti, William G. Axinn, and Kishor Gajurel. 1997. "Sampling Strategies for Rural Settings: A Detailed Example from the ChitwanValley Family Study, Nepal." Nepal Population Journal 6:193-203.

Bartsch, William H. 1977. Employment and Technology Choice in Asian Agriculture. New York: Praeger.

Bastola, Tunga S. 1998. "Agro-Biodiversity." Pp. 28-80 in A Compendium on Environment Statistics 1998 Nepal. Kathmandu, Nepal: Central Bureau of Statistics.

Bennett, Lynn. 1983. Dangerous Wives and Sacred Sisters: Social and Symbolic Roles of High Caste Wopmen in Nepal. New York: Columbia University Press.

Biddlecom, Ann E., William G. Axinn, and Jennifer S. Barber. 2005. "Environmental Effects on Family Size Preferences and Subsequent Reproductive Behavior in Nepal." Population and Environment 26(3):183-206.

Biggs, Stephen, Scott Justice, and David Lewis. 2011. "Patterns of Rural Mechanization, Energy and Employment in South Asia: Reopening the Debate." Economics and Political Weekly 46:78-82.

Binswanger, Hans P. 1978. The Economics of Tractors in South Asia. New York: Agricultural Development Council; Hyderabad, India: International Crops Research Institute for the Semi-Arid Tropics.

Biswas, Margaret R. 1994. "Agriculture and Environment: A Review, 1972-1992." Ambio 23(3):192-97.

Blossfeld, Hans Peter and Johannes Huinink. 1991. "Human Capital Investments or Norms of Role Transition? How Women's Schooling and Career Affect the Process of Family Formation." American Journal of Sociology 97:143-68.

Bongaarts, John. 2008. "Fertility Transition in Developing Countries: Progress or Stagnation?" Studies in Family Planning 39(2):105-10.

Boserup, Ester. 1965. The Conditions of Agricultural Growth: The Economics of Agrarian Change under Population Pressure. Chicago, IL: Aldineand Allen \& Unwin.

Brauner-Otto, Sarah R., William G. Axinn, and Dirgha J. Ghimire. 2007. "The Spread of Health Services and Fertility Transition.” Demography 44(4):747-70.

Brien, Michael J. and Lee A. Lillard. 1994. "Education, Marriage, and First Conception in Malaysia." Journal of Human Resources 29:1167-204.

Cain, Mead. 1977. "The Economic Activities of Children in a Village of Bangladesh." Population and Development Review 3(3):201-27.

— 1981. "Risk and Insurance: Perspective on Fertility and Agrarian Change in India and Bangladesh." Population and Development Review 7(3):435-74.

. 1985. "On the Relationship between Landholding and Fertility." Population Studies $39: 5-15$. 
Caldwell, Bruce K. and John C. Caldwell. 2003. "Below-Replacement Fertility: Determinants and Prospects in South Asia." Journal of Population Research 20(1):19-34.

Caldwell, John C. 1980. "Mass Education as the Determinant of the Timing of Fertility Decline." Population and Development Review 6(2):225-55.

- 1982. Theory of Fertility Decline. New York: Academic Press.

Caldwell, John. C., P. H. Reddy, and Pat Caldwell. 1983. "The Causes of Marriage Change in South India." Population Studies 37(3):343-61.

Carr, David L., William K. Y. Pan, and Richard E. Bilsborrow. 2006. "Declining Fertility on the Frontier: The Ecuadorian Amazon." Population and Environment 28(1):17-39.

Cleaver, Harry M. 1972. "The Contradictions of the Green Revolution." American Economic Review 62:177-88.

de Sherbinin, Alex, Leah K. VanWey, Kendra McSweeney, Rimjhim Aggarwal, Alisson Barbieri, Sabine Henry, Lori M. Hunter, Wayne Twine, and Robert Walker. 2008. "Rural Household Demographics, Livelihoods and the Environment." Science DirectGlobal Environmental Change 18:38-53. Retrieved March 13, 2010 (www.populationenvironmentresearch.org).

Entwisle, Barbara, John Casterline, and Hussein Sayed. 1989. "Village as Contexts for Contraceptive Behavior in Rural Egypt.” American Journal of Sociology 54:1019-34.

Entwisle, Barbara and W. M. Mason. 1986. "Multilevel Effects of Socioeconomic Development and Family Planning Programs on Children Ever Born." American Journal of Sociology $91(3): 616-49$.

ESCAP (Economic and Social Commission for Asia and the Pacific). 2007. 2007 ESCAP Population Data Sheet. Bangkok, Thailand: Emerging Social Issues Division, United Nations Economic and Social Commission for Asia and the Pacific.

Filmer, Deon and Lant Pritchett. 1997. "Environmental Degradation and the Demand for Children: Searching for the Vicious Circle." World Bank Policy Research Paper No. 1623, World Bank, Washington, DC.

Fricke, Thomas E. 1988. Himalayan Households: Tamang Demography and Domestic Processes. Ann Arbor, MI: UMI Research Press.

Frost, Melanie. 2010. "Landholding and the Demand for Children in Rural Nepal." Presented at the annual meetings of the Population Association of America, Dallas, TX, April 16.

Ghimire, Dirgha J. and William G. Axinn. 2010. "Community Context, Land Use and First Birth.” Rural Sociology 75(3):478-513.

Ghimire, Dirgha J. and Lynette F. Hoelter. 2007. "Land Use and First Birth Timing in an Agricultural Setting." Population and Environment 28(6):289-320.

Griffin, Keith. 1974. The Political Economy of Agrarian Change. London, England: Macmillan.

Gubhaju, Bhakta B. 2011. "Demographic Transition in Southern Asia: Challenges and Opportunities." Asia-Pacific Population Journal 26(4):1-2.

Hazell, Peter B. R. and C. Ramaswamy. 1991. The Green Revolution Reconsidered: The Impact of High-Yielding Rice Varieties in South India. Baltimore, MD: Johns Hopkins University Press.

Hill, Jason, Stephen Polasky, Erik Nelson, David Tillman, Hong Huo, Lindsay Ludwig, James Newmann, Haochi Zheng, and Diego Bonta. 2009. "Climate Change and Health Costs of Air Emissions from Biofuels and Gasoline." National Academy of Sciences of the USA 106(6):2077-82.

Hirschman, Charles. 1985. "Premarital Socioeconomic Roles and the Timing of Family Formation: A Comparative Study of Five Asian Societies.” Demography 22:35-59.

Hirschman, Charles and Ronald Rindfus. 1980. "Social, Cultural and Economic Determinants of Age at Birth of First Child in Peninsular Malaysia.” Population Studies 34:50718.

Jacoby, Erich H. 1972. "Effects of 'Green Revolution' in South and South-East Asia.” Modern Asian Studies 6(1):63-69.

Jensen, Eric R. 1990. "An Economic Analysis of the Old-Age Security Motive for Childbearing.” International Economic Review 31(4):953-68. 
Leone, Tiziana and Gianpiero Dalla Zuanna. 2003. "Impact and Determinants of Sex Preference in Nepal." International Family Planning Perspectives 29(2):69-75.

Link, Cynthia F. 2011. "Spousal Communication and Contraceptive Use in Rural Nepal: An Event History Analysis." Studies in Family Planning 42(2):83-92.

Lipton, Michael. 1989. New Seeds and Poor People. Baltimore, MD: Johns Hopkins University Press.

Loughran, David and Lant Pritchett. 1996. "Environmental Scarcity, Resource Collection, and the Demand for Children in Nepal." World Bank Policy Research Working Paper No. 1623. Washington, DC: World Bank.

Majumdar, Prasanta K., Dilip K. Dolui, and Hiron K. Banerjee. 2001. "Child Labour, Education and Fertility." A paper presented at the XXIVth International Union for the Scientific Study of Population (IUSSP) General Population Conference, Salvador, Brazil, August 18-24.

Mamdani, Mahmood. 1972. The Myth of Population Control: Family, Caste, and Class in an Indian Village. New York: Monthly Review Press.

Mason, Karen O. 1987. "The Impact of Women's Social Position on Fertility in Developing Countries." Sociological Forum 2:718-45.

Mellor, John W. 1976. The New Economics of Growth. Ithaca, NY: Cornell University Press.

Ministry of Agriculture and Cooperatives. 2003. Nepal Fertilizer Use Study. Kathmandu, Nepal: Ministry of Agriculture and Cooperatives.

Notestein, Frank W. 1953. "Economic Problems of Population Change." Pp. 13-31 in The Economics of Population and Food Supplies. Proceedings of the Eighth International Conference of Agricultural Economics. London, England: Oxford University Press.

Paige, Jeffrey M. 1975. Agrarian Revolution: Social Movements and Export Agriculture in the Underdeveloped World. New York: Free Press.

Pariyar, Madan, Khadga Bahadur Shrestha, and Narahari Dhakal. 2001. "Baseline Study on Agricultural Mechanization Needs in Nepal." Facilitation Unit, Rice-Wheat Consortium for the Indo-Gangetic Plains, National Agricultural Science Centre, New Delhi, India.

Pimentel, David and Marcia Pimentel. 1991. "Comment: Adverse Environmental Consequences of the Green Revolution." Pp. 239-332 in Resources, Environment and Population: Present Knowledge, Future Options, edited by Kingsley Davis and Mikhail S. Bernstam. New York: Population Council and Oxford University Press.

Rani, Seema and A. Malaviya. 1992. "Farm Mechanization and Women in Paddy Cultivation." Pp. 261-67 in Women in Agriculture: Their Status and Role, vol. 1, edited by R. K. Punia. New Delhi, India: Northern Book Centre.

Rauniyar, Ganesh P. and Frank M. Goode. 1996. "Managing Green Revolution Technology: An Analysis of a Differential Practice Combination in Swaziland." Economic Development and Cultural Change 44(2):413-37.

Rosenzweig, Mark R. 1977. "The Demand for Children in Farm Households." Journal of Political Economy 85(1):123-46.

Rosenzweig, Mark R. and R. Evenson. 1975. "Fertility, Schooling and the Economic Contribution of Children in Rural India: An Econometric Analysis." Yale Growth Center Discussion Paper No. 239. New Haven, CT: Yale University.

Sathar, Zeba Ayesa and James F. Phillips, eds. 2001. Fertility Transition in South Asia. New York: Oxford University Press.

Schutjer, Wayne A. and C. Shannon Stokes. 1982. "Agricultural Policies and Human Fertility: Some Emerging Connections." Population Research and Policy Review 1:225-44.

Schutjer, Wayne A. and Marlin G. Van der Veen. 1977. "Economic Constraints on Agricultural Technology Adoption in Developing Nations." United States Agency for International Development Occasional Paper No. 5. Washington, DC: USAID.

Scott, James C. 1977. The Moral Economy of the Peasant: Rebellion and Subsistence in Southeast Asia. New Haven, CT: Yale University Press.

Self, Sharmistha. 2008. "Developing Countries and Fertility: Role of Agricultural Technology." International Journal of Development Studies 7(1):62-75. 
Sen, Sudhir. 1975. Reaping the Green Revolution: Food and Jobs for All. Maryknoll, NY: Orbis Books; New Delhi, India: Tata McGraw-Hill.

Shiva, Vandana. 1993. Monocultures of the Mind: Perspectives on Biodiversity and Bioechnology. Penang, Malaysia: Zed Books and Third World Network.

Shivakoti, Ganesh P., William G. Axinn, Prem Bhandari, and Netra Chhetri. 1999. "The Impact of Community Context on Land Use in an Agricultural Society." Population and Environment 20:191-213.

Skocpol, Theda. 1982. "Review: What Makes Peasants Revolutionary?" Comparative Politics 14(3):351-75.

Stash, Sharon. 2001. "Son Preference and the Dynamics of Fertility Decision-Making among Wives and Their Husbands in Rural Nepal." Pp. 300-328 in Fertility Transition in South Asia, edited by Z. A. Sathar and J. F. Phillips. New York: Oxford University Press.

Stokes, C. Shannon. 1995. "Explaining the Demographic Transition: Institutional Factors in Fertility Decline.” Rural Sociology 60(1):1-22.

Stokes, C. Shannon and Wayne A. Schutjer. 1984. "Access to Land and Fertility in Developing Countries.” Pp. 195-215 in Rural Development and Human Fertility, edited by W. A. Schutjer and C. S. Stokes. New York: Macmillan.

Suwal, Juhee V. 2001. "Socio-cultural Dynamics of First Birth Intervals in Nepal." Contribution to Nepalese Studies 28(1):11-33.

Togunde, Dimeji and Samantha Newman. 2005. "Value of Children, Child Labor, and Fertility Preferences in Urban Nigeria.” West Africa Review 7. Retrieved June 13, 2010 (http://www.africaknowledgeproject.org/index.php/war/article/view/290).

Tuladhar, Jayanti M. 1989. "The On-set of Fertility Decline in Nepal." Asia-Pacific Population Journal 4(3):15-30.

Tuladhar, Jayanti M., John Stoeckel, and Andrew Fisher. 1982. "Differential Fertility in Rural Nepal.” Population Studies 36(1):81-85.

Vosti, Stephen A., Julie Witcover, and Michael Lipton. 1994. "The Impact of Technology Change in Agriculture on Human Fertility: District-level Evidence from India." Environmental and Production Technology Division (EPTD) Discussion Paper No. 5. Washington, DC: International Food Policy Research Institute.

Waite, Linda J. and Ross M. Stolzenberg. 1976. "Intended Childbearing and Labor Force Participation of Young Women: Insights from Nonrecursive Models." American Sociological Review 41 (2):235-52.

Wolf, Eric R. 1969. Peasant Wars of the Twentieth Century. New York: Harper and Row.

World Bank. 2008. World Development Report 2008: Agriculture for Development. Washington, DC: World Bank Publications.

Yabiku, Scott T. 2004. "Marriage Timing in Nepal: Organizational Effects and Individual Mechanisms." Social Forces 83(2):559-86. 